\title{
The Problems of the Obligations Fulfillment on the Phase of Unfinished Construction
}

\author{
Lubov Sitdikova
}

Anna Shilovskaya

\author{
Svetlana Starodumova
}

\author{
Renata Lenkovskaya
}

Alla Neznamova

\author{
Russian State Social University (RSSU), Moscow, Russian Federation
}

Building 1, Vilgelma Pika Street, 4, Moscow, 129226, Russian Federation

\section{Doi:10.5901/mjss.2015.v6n6s5p85}

\begin{abstract}
In the article the analysis of litigation practice on the fulfillment of the obligations in sphere of building investment contracts is made. On the basis of the revealed problems, that arise during the investment contract fulfillment the authors of the article offer the ways of its' decision. Legislation of the Russian Federation provides only general rule that the relationship between the investor and the client are determined by the contract of construction. However the existing mechanism for the application of this rule is extremely diverse and has been repeatedly changed, which allowed some unscrupulous developers and contractors not only not to fulfill its commitments, but also avoid any responsibility. Investment contracts in construction require special attention to procedures for the performance of contractual obligations. Key problematic aspects of performance of the obligation on the phase of unfinished construction were highlighted by the authors of the article. Among the derivations made during the research the most important are the following: that fulfillment of the obligations in sphere of creation, reconstruction and operation of the real estate depends on economic, legal and administrative mechanisms, existing in the state, and that the investment agreements possess the civil nature.
\end{abstract}

Keywords: investor, (builder, developer), investment contract, share building, due fulfillment of the obligation.

\section{Introduction}

\subsection{Introducing the Problem}

The questions of increase of investment attractiveness of Russian regions, improvement of the investment climate in General, simplification of administrative procedures associated with the construction or reconstruction of real estate, are closely in contact with the practice of ongoing investment projects' performance.

According to some reports, the total number of Russian citizens who suffered from various irregularities admitted in the conclusion of contracts in the construction sphere is more than 150 thousand people. The accounting of the investors - legal entities who participated in the projects that remained unrealized, in the modern period does not exist.

General provisions on the execution of the obligations established in article 309 of the Civil code - appropriate fulfillment in accordance with conditions of the obligations, requirements of law and other legal acts, and in their absence - in accordance with the customs of business turnover or commonly applicable requirements are being fully applied to investment contracts in the construction industry.

The fulfillment of the obligations and the ensuring of obligations fulfillment are carried out under the provisions of Chapter 22-23 the Civil code, which shall apply to any contract regardless of its specific type and subject, while in section IV the Civil code provides for additional guarantees for the proper performance of certain obligations (for example, in relation to a building contract there are rules established under article 748 of the Civil code about the control and supervision over the execution of works). The timely and detailed information submitted by the builder (including information that is placed on the information resources) assists to the due fulfillment of the obligations (Volkova M.A., Sitdikova L.B., Starodumova S.J., Shilovskaya A.L., 2015). 


\subsection{Importance of the Problem}

The investment contracts in construction require special attention to the procedures for performance of contractual obligations (Shumejko, 2009; Kulakov, 2011), due to a number of reasons, namely: usually many-subject composition, complex character (the subject of the contract may include the condition of the construction of the building, and about the infrastructure), period of performance (which is unpredictable for a number of reasons), and in some cases, the inclusion the public law entities in the list of the subjects of the contract.

Problems of execution of obligations under investment contracts in construction activities can be grouped as follows. As it is proposed, the first group should include those united by general economic or legal realities: economic strategy, chosen by the investor, the contractor or other participants of construction process; changes in legislation, the role of state structures in sphere of construction.

The second group probably should include the circumstances connected with the legal content of the investment project, with the the good faith of the fulfillment of the obligations assumed by the parties, compliance with the deadlines of the construction unfinished by construction.

It should be noted that the specific form of the contract on the construction (reconstruction) of buildings, the qualification of this contract, the number of participating parties largely determine the problems of execution of contractual obligations. In connection with this the litigation practice which was studied in the framework of this article, concerns contracts of participation in share building and investment treaties, including with the participation of public legal entities.

The educational and monographic works of the following authors were focused at the named topic: Braginsky and Vitryansky, 2011; Mozolin, 1974. Some aspects of the problem were analyzed in article of Volkova et. al., 2015. Among the foreign sources we can distinguish the following: Berle and Means, 1932, Ackerman et. al., 2002. Waldron, 1988., Ellickson, 1993. The complex research of the different aspects of the problem was made in dissertations of Kulakov,2011, Khomenko, 2007, Shumejko, 2009.

\subsection{Hypotheses and Their Correspondence to Research Design}

The purpose of the study is the development of scientific and practical views on the civil mechanism of the proper fulfillment of the obligations at stage of unfinished construction.

Objectives of the study:

- to explore civil-legal regulation of the obligations on creation of objects of construction;

- to propose an common characteristic of obligations at the stage of unfinished construction;

- to highlight the problems of performance of obligations at the stage of unfinished construction;

- to consider the participants of the relationships of investment activities that accompany the creation of objects of construction;

- identify features of investment relations in the construction industry;

- to offer ways of solution of the problems of inadequate execution of the obligations, arising at the stage of unfinished construction.

The following key problematic aspects of performance of the obligation on the phase of unfinished construction were highlighted:

- a forced change of persons in the obligation, causing the attraction of additional funds, and the publication of a special legal act by the authorities of subjects of the Federation

- the emergence of new conditions imposed by the public authorities or local self-government, that are not fulfilled by third parties involved in construction, not investment activities.

We believe that to solve the above problems, there is a need for mandatory reliability evaluation of capital investments, and the choice of the optimal type of contract entered into with the builder.

We also consider that it is necessary to legally fix such participant of the investment activities as the "developer" that would better regulate investment relationships.

The necessity of the implementation and legal fixation of the following models of investment relations was identified: 1) the contract of sale of future things; 2 ) the agreement on ordinary partnership; 3 ) the contract of participation in share building.

It is necessary to fix legal safeguards obligations in the list of essential terms of the investment contract.

In order to ensure proper fulfillment of investment contract' terms, it is appropriate to legally stipulate the implementation and maintenance of registers of investment activities and monitoring of the condition of the immovable 
property granted for construction or reconstruction.

We suppose that it is necessary to enshrine the right of the investor (customer, customer) to sue the recognition of property rights towards the object under construction, although the object has not been transferred from the builder.

The rules on the monitoring of construction, about possible sanctions applicable to the co-investor, developer, or other participants of the investment project may be included in the legislation as guarantee for the realization of this right.

\section{Method}

During the study the authors relied upon general and private methods of cognition: historical, legal, formal-legal, comparative legal, sociological and others. The main method is a system-structural which helped to reveal legal nature of the investment activity in connection with other phenomena, as well as the existing problems in this area.

The combination of legal, historical and comparative legal methods allowed us to identify the specifics impact of the historical conditions at the development of investment in construction, in particular of the economic and political factors influencing the increase of the investment attractiveness, including simplification of administrative procedures for entering building objects in operation.

Formal legal method made it possible to analyze legal rules governing investment relations describing the general conditions for the fulfillment of obligations in sphere of real estate construction, to identify gaps and inaccuracies in the current legislation and propose ways of solving them.

On the basis of the sociological method, suggestions and recommendations based on specific information obtained from official sources, materials, periodicals, Internet resources, standards, legal-reference systems and the media the reasoned conclusions were made.

Systemic-structural method provided the authors with the opportunity to review the investment activity as a special kind of obligations associated with building works.

\section{Results and Discussion}

During the research we came to conclusion that the procedure of the obligations fulfillment on creation, reconstruction and operation of the real estate objects is being influenced by both economic and legal and administrative mechanisms established in the state. We consider, however, that the investment agreements are of a civil nature. During the consideration of the proper fulfillment of its construction obligations, we revealed the problems of good faith in the conduct of the parties, because on the one hand the fulfillment relates to the keeping the terms of building procedure, on the other - with the procedure of putting the object into operation, that has public-legal character.

Special attention in the study was given to the terminology and in particular to the notions "developer" and "development activities", "investor", "builder (contractor, subcontractor)".

We believe that further prospective directions of the research in field of execution of obligations on the stage of unfinished construction will allow to eliminate the most common violations of the participants rights in investment obligations.

In the first group of problems we can distinguish four different positions of legal or economic profile. As it is noted by $A$. B. Khomenko, the creation, reconstruction and operation of real estate is a type of entrepreneurship activity, that is realized in private-law allowable mode. But at the same time it is realized basing on the peremptory norms set forth in city planning, housing, environmental, land law, i.e. in light of public-law norms set by the state (Khomenko, 2011).

Existing jurisprudence is replete with examples of improper performance of obligations in the implementation of projects, which are legally formalized in different ways.

First, because of incorrect economic calculations and of general consequences of the crisis phenomena in the economy in many investment projects there is a change of persons in the obligation. The construction activity requires quite a large amount of money resources and in some cases - also publication of a special legal act by the bodies of state power of subject of the Russian Federation, therefore in case of the change of persons in the obligation, such change may actually be delayed for an indefinite period of time.

At the same time, if the contract was concluded under the provisions of the Law № 214-FZ "About participation in share building of apartment houses and other real estate and on amendments to some legislative acts of the Russian Federation" (hereinafter - the Law № 214-FZ), the project participants have obtained some legal possibilities for protection from the state. But the Law No. 39 "On investment activity in the Russian Federation, that are implemented in the form of capital investments" (hereinafter - the Law № 39) such guarantees does not contain.

The law № 214, in particular, in the article 12 complements general rules for the performance of obligations by 
specifying time of fulfillment (time of signing the instrument of transfer of a new building) - for the developer and the moment of payment of the contract price - to the participant of share building (at the same time, article 12 of the Law also in this case indicates the time of signing the instrument of transfer of a new building).

Secondly, in some situations, the project is disrupted because of the bankruptcy of one of its participants.

Thirdly, because of the presence in the construction activities of certain public law grounds in the implementation of the investment project in some cases new conditions are being imposed by public authorities or local self-government.

All three these problems cannot be predicted at the stage of conclusion of the contract, even if one side is a publiclegal entity. It is impossible to offer the optimum solution by creating a mechanism for the protection of investor rights. Although for example for share participation in construction the rules of evaluation of financial stability of the builder are established, the norms of which were approved by the Russian Government (clause 5, article 23 of the Law № 214), and also the register of citizens whose funds borrowed for construction of apartment houses and whose rights are violated (paragraph 7 of article 23 of the Law № 214-FZ) is also provided.

However, the controlling authority is entitled to consider complaints from individuals about the developers violations of the requirements of the Law № 214-FZ. Unscheduled and scheduled inspections are conducted after the receipt of a complaint ( 8-13 article 23 of the Law № 214-FZ), and after a finding of violation, the supervisory authority will issue to the developer a notice on elimination of the revealed violations, with pointing specific time frame of elimination of violations.

In particular prescriptions are issued in case of administrative offences, namely: 1) in case of attracting funds from citizens for share building of apartment houses by the builder in violation of the requirements of the Law № 214-FZ; 2) in case of publication of the project Declaration containing false information; 3 ) in case of absence of the fact of submission of reporting to the controlling authority or the submission of statements containing false information; 4) in case of absence of the fact of submission of information and documents lawfully requested by the controlling authority (when documents are required for the performance of the functions of the state control (supervision) over the activities of the developer on attracting of citizens' investments in the construction of apartment buildings).

For investors participating in construction on the basis of other contractual structures, there is no equal legal protection, whereby for this category of persons is actually the only (and not uncontroversial) only reliability evaluation of capital investments and the choice of the optimal type of contract entered into with developer looks as a guarantee.

That is why in modern Russia so named "development activity", which involves an intermediary element between the investor and the developer, which bears the obligations of an organizational nature received certain popularity.

At the same time, the legislation contains no definition of the terms "developer" and "development activities", although their appearance could lead to the emergence of a new model investment legal relation under the following scheme "investor - developer - builder (contractor, subcontractor)".

The second group of problems related to the execution of investment contracts in construction activities, in our opinion may be presented by the following positions.

First, it is essential terms of the contract which are determined by the specific type of such contract. Due to the legal positions set forth in the Resolution of Plenum of the Supreme Arbitrage Court of the Russian Federation № 54 dated 11 July 2011, in the modern period, there are following models of investment legal relations: the contract of sale of future things, the agreement on ordinary partnership and - indirectly - the contract of participation in share building, in frames of the essential conditions of which the investor may provide legal safeguards of the obligations.

In practice in investment treaties in the field of construction the determination of material breach of contract is being used, for example: significant violations of the terms of the contract include: 1) any significant deviation from the main technical parameters and volumes of financing (deviation values of these indicators more than 10\%); 2) breach in implementation stages of the investment project because of non-fulfillment or breach of contract by one of the parties.

Secondly, it is the honesty of the fulfillment of assumed contractual obligations. As indicated by M. I. Braginsky and V.V. Vitryansky the execution terminates the obligation if it is proper: if it was made by appropriate person, to the proper person, properly, in the proper place, the proper subject and at the appropriate time. Proper execution demonstrates integrity, but in construction sphere proper execution is closely associated with the procedure of putting into operation, which wears the publicly-legal character (Braginsky and Vitryansky, 2014).

Thirdly, the provisions of the investment agreement about observance of the terms of construction may also be considered in the range of problems of the proper execution. This problem is consolidated with the aspects of the interaction between the investor (builder, developer) with public structures, which were considered at the first group. It should be mentioned that some authors, who deny civil-legal nature of investment agreements and were inclined to consider the priority of administrative-legal regulation in this sphere (Mozolin, 1974), have made conclusions about the possibilities of state entities to streamline observance of the terms of construction by the means of keeping registers of the investment activities and monitoring of the condition of the property granted for the construction or reconstruction. 
Fourthly, we should mention about the unfinished construction, when in fact the erection of the building was suspended, and the deadlines, stipulated in the contract expire, and the part of the building, that was erected cannot be used by the investor.

One may specify the following ways of solving problems arising from the enforcement of the investment contract in construction: terminate the contract; apply the methods of provision of execution of obligations named in the Civil code; apply the provisions on liability provided by the contract or by the law.

The available judicial practice confirms this conclusion. For example, in the Decision of the Federal Arbitrage Court of Moscow court district № A40-26819/03-53-248 while terminating the contract on investment project implementation, concluded between a non-profit organization and the Property Department of Moscow city and also the Prefecture of administrative district of Moscow, the court proceeded from the breach by the defendant of the essential conditions. Namely for more than five years after the expected date the object was not rebuilt and not been put into operation, as a consequence the administration lost the result, on which counted at the conclusion of the contract.

In another court decision - of the Arbitration court of Moscow № A40-1628/08-50-24 between the claimant and the respondent had concluded an investment contract under which the defendant undertook to build a house, and the plaintiff had to pay for the construction. The house was not built. However, the contract stipulated that if the defendant's breach of the term of the permission to commissioning of the house, the defendant shall pay the plaintiff liquidated damages (penalties) in the amount of $0,1 \%$ of the amount invested under the contract for each day of delay.

Since the contract was not terminated or modified by the parties, the court ordered the Respondent (contractor) to pay liquidated damages, rejecting the defendant's argument about the mixed nature of the contract (construction contract/ordinary partnership) and the argument about the irresistible force, that is associated with unpredictable increase in the estimated cost of construction and the date of completion.

The above-mentioned problems as well as the problems of the first group, often cannot be predicted at the stage of conclusion of the contract. However, in connection with long implementation process as a rule and with the presence of the evident ability of interested persons at least remotely monitor the progress of construction and to use the legal mechanism of compelling to the performance of the obligations, should recognize that they are solvable in the legal way to a greater extent, including using of the claims and litigation.

Minimization of their consequences is possible by establishing in the legal norm of the special norms about the monitoring of construction, about possible sanctions applicable to the co-investors, developer, or other participants of the investment project, just as it is done in the Law № 214-FZ.

In the Federal law of the Russian Federation of December 28, 2013 No. 414-FZ "On amendments to certain legislative acts of the Russian Federation concerning the protection of the rights and legitimate interests of citizens, whose funds are used for construction (creation) of apartment houses and (or) other objects of real estate" the article 23 "State regulation, state control (supervision) in the field of share building of apartment houses and (or) other objects of real estate" of the Law on share participation" is set out in the editorial, which established bases for the control (supervision) towards the builders under the contracts of participation in share building, and scheduled and unscheduled inspections.

So, one of the grounds for carrying out of the scheduled inspection by the controlling authority is the expiration of one year from the date of issue to the entity which attracts monetary funds of citizens for the construction of a building permit or from the date of completion of the last scheduled inspection of such person in the territory of the region of Russian Federation, on which the construction is performed.

As confirmation, one should specify the example where the court upheld the claim on termination of the contract on joint activity, having come to the conclusion that there is a substantial breach of contract, that was expressed in the absence of reports about the performance of the contract, in dereliction of duty on financing of construction, coordination of project documentation, execution of construction works, the termination of the right of economic management on unfinished construction object and the termination of the lease contract of the land plot under it.

\section{Conclusion}

Thus, we have examined the specificity of the problems of the obligations fulfillment on the phase of unfinished construction.

In frames of the research we explored civil-legal regulation of the obligations on creation of objects of construction and proposed common characteristic of obligations at the stage of unfinished construction. We highlighted the problems of performance of obligations at the stage of unfinished construction and identified features of investment relations in the construction industry. Also an attempt was made to offer ways of solution of the problems of inadequate execution of the 
obligations, arising at the stage of unfinished construction.

Finally we came to conclusion that the investment agreements have civil nature despite of the influence of the administrative mechanisms.

\section{References}

Ackerman, B., R. Ellickson, and C.M. Rose (2002). Perspectives on Property Law, 3rd ed. Aspen Law and Business.

Berle A.A. and Means G.C. (1932). The Modern Corporation and Private Property . New York, Macmillan.

Braginsky M.I., Vitryansky V.V. (2011). Dogovornoe pravo: Obschie polozhenya [Contract law: General provisions ]. Moskva: Izdatel'stvo Statut.

Ellickson, R. C. (1993). Property in Land. Faculty Scholarship Series. Paper 411.http://digitalcommons.law.yale.edu/fss_papers/411

Khomenko, A.B. (2007). Grazdansko-pravovoe regulirovanije investitsij na stroitelstvo objectov predprinimatelskogo naznachenija. Dissertatzia kandidata juridicheskih nauk. [Civil - legal regulation of investment on building of the entrepreneurship objects. Kandidate dissertation. ]. Moskva.

Kulakov V.V. (2011). Slozniye objazatelstva v grazdanskom prave. Dissertatzia doctora juridicheskih nauk. [Complex obligations in civil law. Doctoral dissertation.]. Moskva.

Mozolin V.P. (1974). Pravo SSHA i ekspansia amerikanskih korporatsij] [USA law and the expansion of American corporations ]. Moskva: Izdatel'stvo Moskovskogo Universiteta.

Shumejko, I.Y. (2009). Problemi ispolnenija objazatelstv v grazdanskom prave. Dissertatzia kandidata juridicheskih nauk. [The problems of the obligations' fulfillment in civil law. Kandidate dissertation.]. Rostov.

Volkova M.A., Sitdikova L.B., Starodumova S.J., A.L.Shilovskaya (2015). Legal problems of the information services implementation in Russian civil law. Review of European Studies, Vol. 7, No.6, 243-271. [Online] Available: http://dx.doi.org/10.5539/res.v7n6p273

Waldron, J. (1988). The Right to Private Property. Oxford Univ. Press. 